\title{
Inhibition of Ubiquitin-conjugating Enzyme E2 May Activate the Degradation of Hypoxia-inducible Factors and, thus, Overcome Cellular Resistance to Radiation in Colorectal Cancer
}

\author{
NAVCHAA GOMBODORJ ${ }^{1,2}$, TAKEHIKO YOKOBORI ${ }^{3}$, SHINJI YOSHIYAMA ${ }^{4}$, REIKA KAWABATA-IWAKAWA ${ }^{4}$, \\ SUSUMU ROKUDAI ${ }^{4}$, IKUKO HORIKOSHI $^{4}$, MASAHIKO NISHIYAMA ${ }^{3,4}$ and TAKASHI NAKANO ${ }^{1,5}$ \\ ${ }^{1}$ Department of Radiation Oncology, ${ }^{3}$ Division of Integrated Oncology Research, Gunma University \\ Initiative for Advanced Research, ${ }^{4}$ Department of Molecular Pharmacology and Oncology, \\ Gunma University Graduate School of Medicine, Gunma, Japan; \\ ${ }^{2}$ Department of Radiation Oncology, National Cancer Center, Ulaanbaatar, Mongolia; \\ ${ }^{5}$ Gunma University Heavy Ion Medical Center, Maebashi, Gunma, Japan
}

\begin{abstract}
Background: NSC697923, a ubiquitinconjugating enzyme E2 (UBE2) inhibitor, was suggested as an agent to degrade hypoxia-inducible factor 1 alpha subunit (HIFla), a key factor in radiation resistance. We attempted to clarify whether NSC697923 could overcome radiation resistance. Materials and Methods: Radiation resistance and expression of HIFs were evaluated in radiation-sensitive HCT116 and -resistant SW480 cells treated with or without NSC697923 and radiation under normoxia and hypoxia in vitro and in vivo. We examined NSC697923-regulated genes using RNA sequencing. Results: HIF expression significantly increased under hypoxia with an increase of cellular radiation resistance in vitro and in vivo. The therapeutic activity of NSC697923 was higher in radiation-resistant SW480 than radiation-sensitive HCT116 in vivo. Nextgeneration RNA sequencing revealed that NSC697923 regulated the expression of cell migration-inducing protein, hyaluronan binding (CEMIP) and apelin (APLN) genes, that are related to HIF pathways. Conclusion: NSC697923 might effectively regulate HIF families, and be a promising partner with radiation to overcome resistance.
\end{abstract}

\footnotetext{
Correspondence to: Professor Masahiko Nishiyama, Department of Molecular Pharmacology and Oncology, Gunma University Graduate School of Medicine, 3-39-22 Showa-Machi, Maebashi, Gunma 371-8511, Japan. Tel: +81 272207962, Fax: +81 272207963,e-mail: m.nishiyama@gunma-u.ac.jp

Key Words: Colorectal cancer, radiation therapy, hypoxia, radiation resistance, UBE2 family, NSC697923.
}

Progress in perioperative management and adjuvant therapy has led to improved survival for patients with colorectal cancer (CRC) (1-3). However, advanced CRC presents serious obstacles to radical resection: Advanced CRC, especially in the rectum and anal canal, enhances the risk of local recurrence and colostomy following abdominal peritoneal resection (4). It has been reported that adjuvant radiation therapy is very effective and is often performed to eliminate CRC cells near the anal canal $(5,6)$. Overcoming radiation resistance is vital for avoiding abdominal peritoneal resection and local recurrence.

Significant areas of rapid growth in tumors are located at a distance from supporting blood vessels, which results in the formation of a microenvironment low in oxygen and nutrients (7-9). Hypoxia-inducible factor 1-alpha subunit (HIF1 $\alpha$ ) and hypoxia-inducible factor 2-alpha subunit (HIF2 $\alpha$ ), also known as EPAS1, are essential factors in maintaining cellular oxygen homeostasis and adaptation to hypoxia (10-12). Generally, tumor cells that respond to these hypoxic conditions acquire resistance to radiation therapy and most types of chemotherapy in various cancer types (13-16).

High expression of HIF $1 \alpha$ and $-2 \alpha$ has been associated not only with radiation resistance but also poor prognosis in CRC (17-19). Lee et al. reported that HIF1 inhibitor alone strongly suppressed proliferation of the radiation-sensitive CRC cell line HCT116 in in vivo analysis (20), but the combination effects of HIF1 $\alpha$ targeting and radiation on CRC cells, especially radiation-resistant cell lines, have not yet been analyzed as far as we are aware.

Recently it was reported that targeting the ubiquitinconjugating enzyme E2 (UBE2) family prevents HIF1 $\alpha$ and $-2 \alpha$ degradation by proteasome systems $(21,22)$. Some 
A

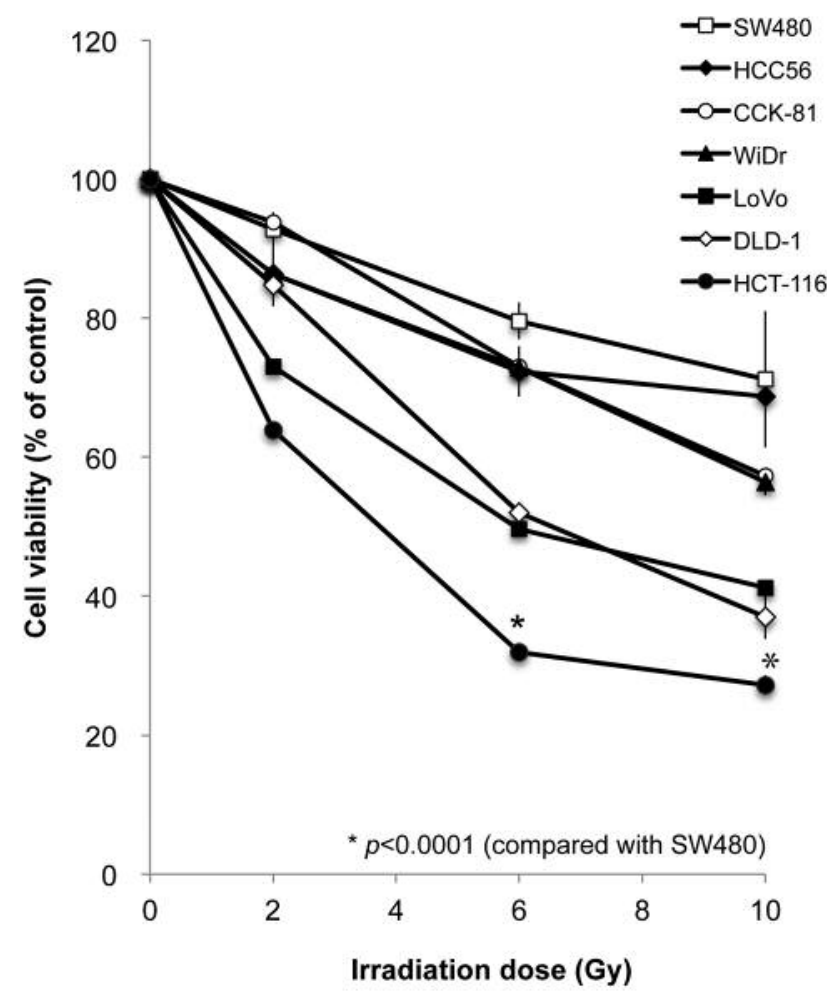

B

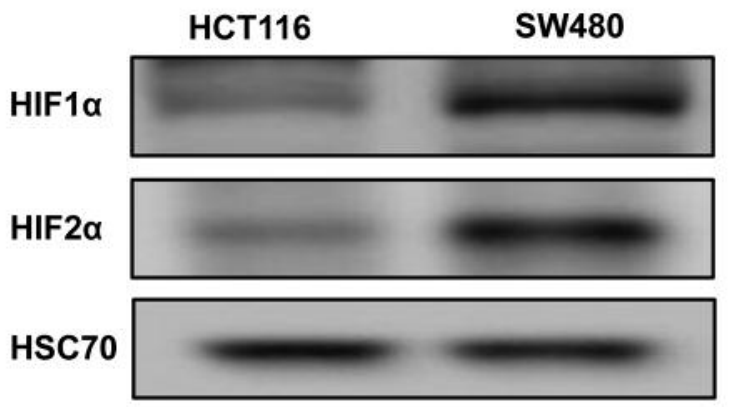

Figure 1. Radiation sensitivity in colorectal cancer (CRC) cell lines under normoxia. A: Cell viability in different CRC cell lines. These cells were irradiated at 2, 6, and 10 Gy. Radiation sensitivity in HCT116 was higher than that in SW480 cells (p<0.0001). From these data, SW480 and HCT116 cells were identified as being radiation-resistant and radiation-sensitive CRC cell lines, respectively. B: Western blotting of hypoxiainducible factor 1 alpha subunit (HIF $1 \alpha$ ) and $-2 \alpha$ baseline expression in SW480 and HCT116 cells under normoxia. The baseline expression of HIF1 $\alpha$ and $-2 \alpha$ was higher in radiation-resistant SW480 cells than in radiation-sensitive HCT116 cells. Heat-shock cognate protein 70 (HSC70) was used as a loading control.

researchers reported several inhibitors of UBE2 family genes as antitumor agents (23-25), but the potential of these UBE2 inhibitors as radiation modulators has not yet been established. We, thus, focused on the UBE2 inhibitor NSC697923, which was recently reported as a promising candidate compound that can induce strong inhibition of proliferation and survival in diffuse large B-cell lymphoma and neuroblastoma (23-25).

The purpose of this study was to elucidate whether NSC697923 can actively overcome radiation resistance in CRC cells by regulating HIF1 $\alpha$ and $-2 \alpha$ in vitro and in vivo using radiation-sensitive HCT116 and radiation-resistance SW480 cells. We also examined other probable action determinants of NSC697923, using a next-generation sequence (NGS) analysis system.

\section{Materials and Methods}

Cell lines and reagents. The human CRC cell lines HCT116, SW480, HCC56, CCK-81, WiDr, LoVo, and DLD-1 were purchased from the Japanese Collection of Research Bioresources Cell Bank (Tokyo, Japan), the RIKEN Cell Resource Center of Biomedical Research (Tsukuba, Japan), and American Type Culture Collection (Manassas, VA, USA). These cells were cultured in RPMI-1640, Ham's, Eagle's minimum essential medium or Dulbecco's modified Eagle's medium (Wako, Osaka, Japan) supplemented with $10 \%$ fetal bovine serum and $1 \%$ penicillin and streptomycin antibiotics, and then incubated at $37^{\circ} \mathrm{C}$ and $5 \% \mathrm{CO}_{2}$. For hypoxia induction, the cells were exposed to hypoxia $\left(1 \% \mathrm{O}_{2}\right)$ using a hypoxic chamber (Billups-Rotenberg, SanDiego, CA, USA) with gas mixtures $(95 \%$ $\mathrm{N}_{2}$ and $5 \% \mathrm{CO}_{2}$ ). Hypoxic plates were coated with a paper sealer, which maintains the hypoxic $\mathrm{O}_{2}$ level inside the well. UBE2 inhibitor NSC697923 and cisplatin were purchased from SIGMAALDRICH Japan (Tokyo, Japan) and Wako laboratory chemicals (Osaka, Japan), respectively.

Cytotoxic analysis. Cell viability was analyzed using the Cell Counting Kit-8 (CCK-8) (Dojindo Laboratories, Kumamoto, Japan). Cells were seeded at $4 \times 10^{3 / 100} \mu \mathrm{l}$ per well in 96 -well plates and allowed to attach for $24 \mathrm{~h}$ with or without hypoxia. After $24 \mathrm{~h}$ incubation, cells were exposed to radiation with/without drug for 72 h. Then $10 \mu \mathrm{l}$ of CCK-8 solution was added to each well and 

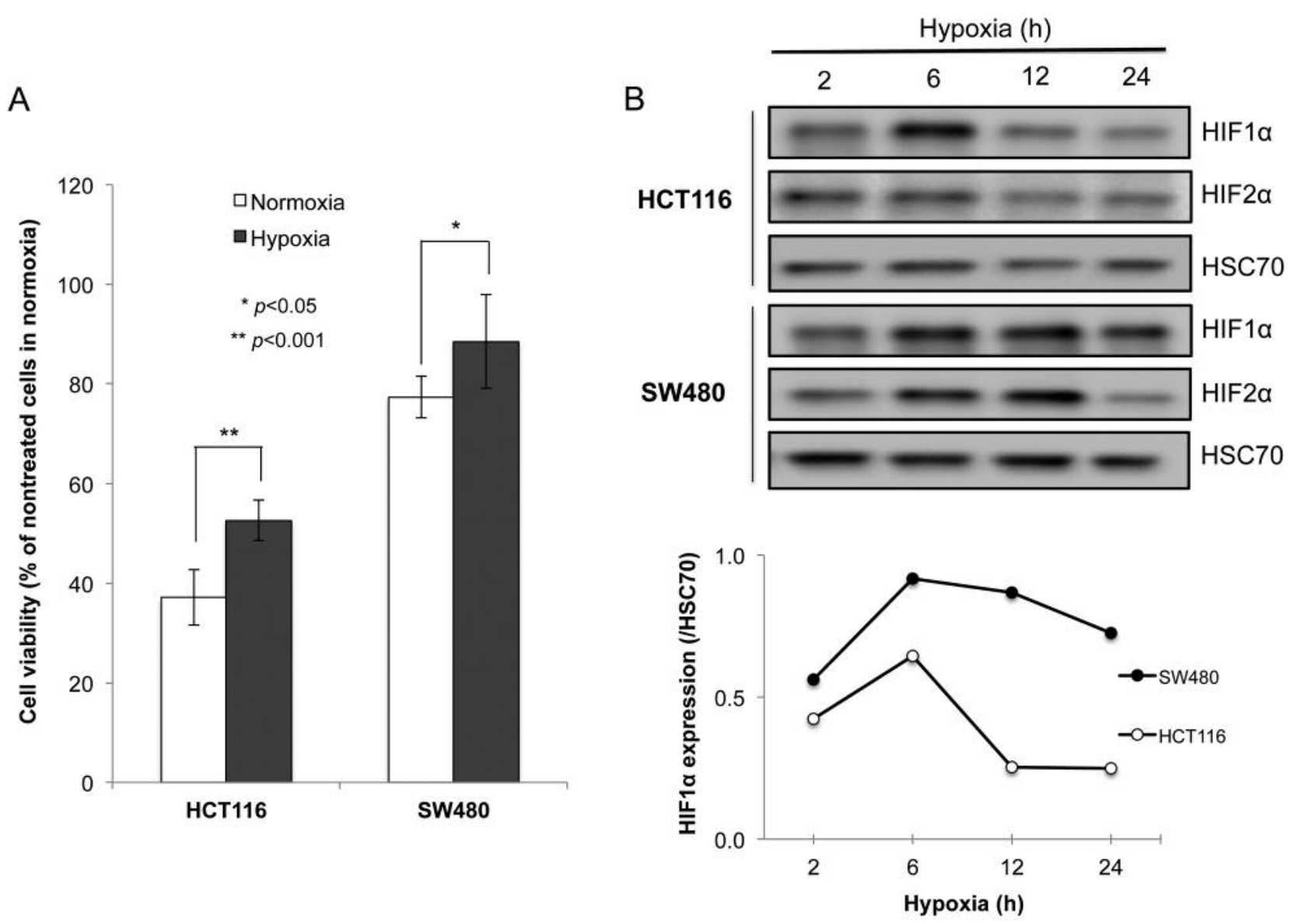

Figure 2. Hypoxia-inducible factor 1 alpha subunit (HIF1 $\alpha$ ) accumulation by hypoxia-induced radiation resistance in SW480 and HCT116 cells. A: Cell viability in SW480 and HCT116 cells treated with 6 Gy radiation under normoxic and hypoxic environments. Hypoxia induced radiation resistance in both cell lines. B: Time course of the expression of HIF1 $\alpha$ and $-2 \alpha$ under hypoxia. Western blotting was used to evaluate expression in SW480 and HCT116 cells. HIF1 $\alpha$ and $-2 \alpha$ expressions were at their highest level 6 hours from initial exposure to hypoxia in both cell lines. The expression of the proteins was normalized to the level of that of heat-shock cognate protein 70 (HSC70). Intensity was measured using the Image J software.

incubated at $37^{\circ} \mathrm{C}$ for $2 \mathrm{~h}$. Absorbance was detected at $450 \mathrm{~nm}$ using a plate reader (BioRad, Hercules, CA, USA), and then the half maximal inhibitory concentration $\left(\mathrm{IC}_{50}\right.$ ) was calculated with MS Excel for each cell line.

Nude mouse experimental system (mouse xenograft model). Eightweek-old male BALB/c nu/nu nude mice received subcutaneous injections of $1 \times 10^{7} \mathrm{CRC}$ cells. Tumor volume was calculated using the formula: Volume $=S^{2} \times L / 2$, where $S$ is the short length of the tumor in $\mathrm{mm}$ and $\mathrm{L}$ is the greatest length of the tumor in $\mathrm{mm}$. The tumor volumes were determined by caliper measurements every 4 days. After the tumor volume had reached $100 \mathrm{~mm}^{3}$, the mice were divided randomly into five groups: Control, radiation alone, NSC697923 alone, NSC697923 plus radiation, and cisplatin plus radiation. Each group had six mice. Cisplatin and NSC697923 were administered intraperitoneally on days 0,4 , and 8 . The doses of cisplatin and NSC697923 were set as one-third of the lethal dose resulting in $50 \%$ mortality $\left(\mathrm{LD}_{50}\right) ; 2 \mathrm{mg} / \mathrm{kg}$ cisplatin and $7.5 \mathrm{mg} / \mathrm{kg}$ NSC697923. Radiation of 6 Gy was performed at day 0 (initial day of treatment) in a single fraction. Mouse tissue samples were harvested on $0,4,8$ and 12 of the experiment. The evaluation of tumor volume and mouse body weight was continued until day 28 .

Radiation. For in vitro study, HCT116 and SW480 in 96-well plates were exposed to hypoxia $\left(1 \% \mathrm{O}_{2}\right)$ for $24 \mathrm{~h}$, then treated with radiation, and evaluated by CCK- 8 assay after $72 \mathrm{~h}$ incubation in normoxia. An X-ray machine (FAXITRON, RX-650, Faxitron XRay LLC, Lincolnshire, IL, USA) with $100 \mathrm{kV}$, Al $0.3 \mathrm{~mm}$ filter was used for radiation treatment. We performed local radiation against tumor with $6 \mathrm{~mm}$ lead shielding using a subcutaneous xenograft mouse model. Radiation was performed at a dose of 6 Gy in single fraction operated (TITAN-225S;Shimadzu Mectem, Inc., Tokyo, Japan) with $200 \mathrm{kV}, 14.6 \mathrm{~mA}$ with $\mathrm{Al} 0.5 \mathrm{~mm}$ and $\mathrm{Cu}$ $0.5 \mathrm{~mm}$ filtration at a distance of $47.3 \mathrm{~cm}$ from the target.

Protein extraction and western blotting. The proteins were extracted using lysis buffer [10 mM Tris- $\mathrm{HCl}$ (pH7.5), $1 \mathrm{mM}$ EDTA, 10\% Glycerol, $0.5 \% \mathrm{NP} 40,400 \mathrm{mM} \mathrm{NaCl}, 4 \mu \mathrm{g} / \mathrm{ml}$ aprotonin, phenylmethylsulfonyl fluoride, proteasome inhibitor MG-132 and 1 $\mathrm{mM}$ and dithiothreitol. Total protein $(10 \mu \mathrm{g})$ was electrophoresed 

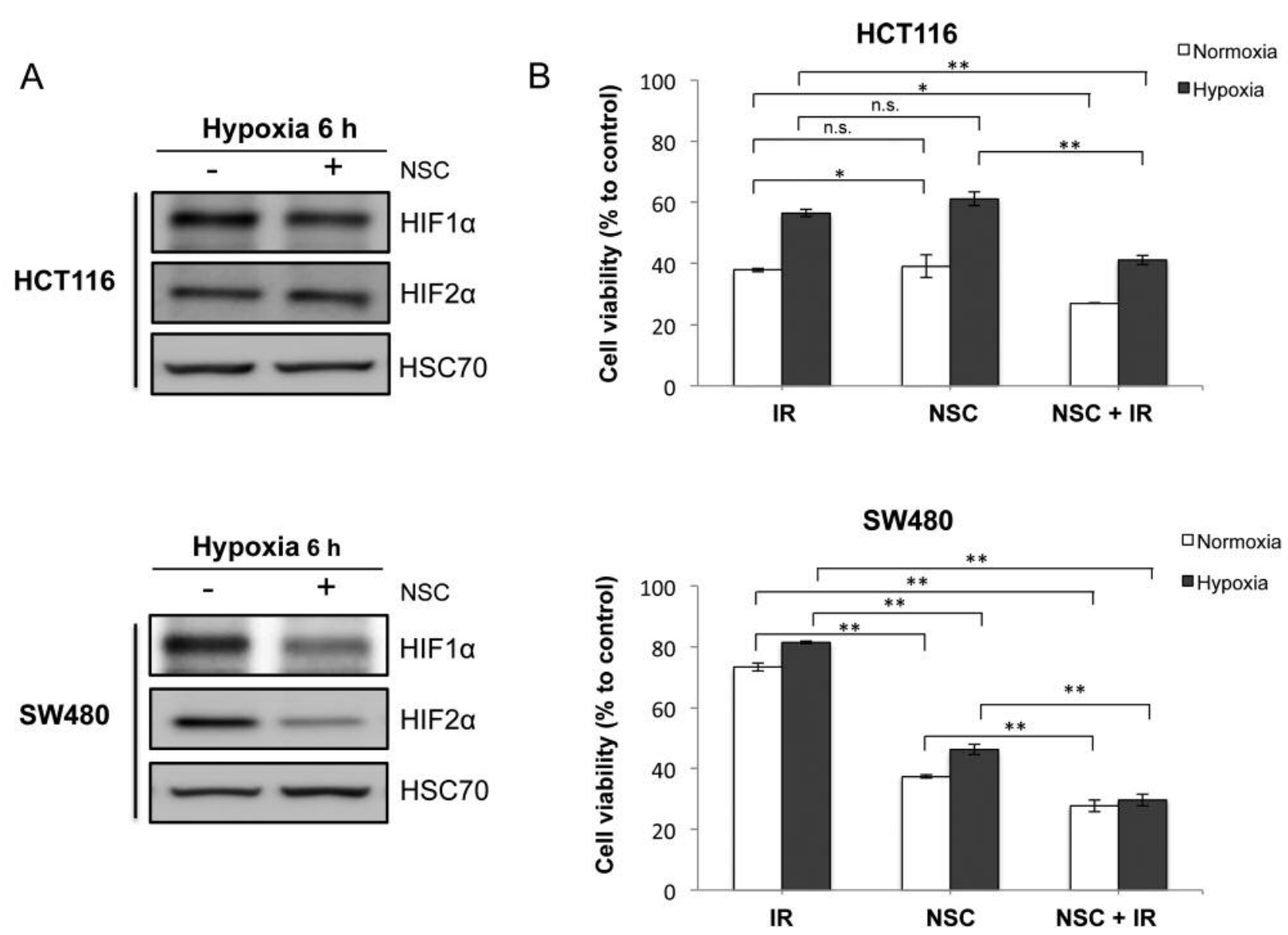

Figure 3. Ubiquitin-conjugating enzyme E2 (UBE2) inhibitor NSC697923 can repress hypoxia-inducible factor 1 alpha subunit (HIF1 $\alpha$ ) and -2 $\alpha$ expression in radiation-resistant SW480 cells under hypoxia. A: HIF1 $\alpha$ and $-2 \alpha$ expression in SW480 and HCT116 cells treated with half maximal inhibitory concentration (IC 50 ) concentration of NSC697923 (NSC) under 6 h hypoxia. Western blotting was used to evaluate the expression in both cells. NSC697923 significantly repressed expression of both HIF1 $\alpha$ and -2 $\alpha$ induced by hypoxia in SW480 cells, but not in HCT116 cells. The expression of these proteins was normalized to the level of heat-shock cognate protein 70 (HSC70). B: Radiation combination with NSC697923 suppressed cell viability of SW480 and HCT116 cells under hypoxia more than radiation alone (HCT116: $5.61 \mu M$ and SW480: $1.87 \mu M$ ). n.s. Not significant; $* p<0.01 ; * * p<0.001$.

on a $10 \%$ polyacrylamide gel, and then electroblotted at $300 \mathrm{~mA}$ for 90 min on a nitrocellulose membrane (Invitrogen). Western blotting was used to confirm the expression of HIF $1 \alpha$ and $-2 \alpha$, and heatshock cognate protein 70 (HSC70). These proteins were detected using rabbit monoclonal antibody to HIF $1 \alpha$ and to HIF $2 \alpha(1: 1,000$ in vitro and 1:500 in vivo) (Cell Signaling Technology Inc., Danvers, MA, USA) and mouse monoclonal antibody to HSC70 (1:3000 in vitro and in vivo) (Santa Cruz Biotechnology, Inc., Dallas, TX, USA). HSC70 expression was used as a loading control. The signals were detected using the ECL Western Blotting Detection System and an Image Quant LAS 4000 machine (GE Healthcare Life Sciences Inc., Chicago, IL, USA).

RNA-sequencing. Total RNA was extracted by using NucleoSpin RNA kit (Clontech) following the manufacture's instructions. One microgram of total RNA was used to generate sequencing libraries of the barcoded fragment using the TruSeq Stranded mRNA Sample
Prep Kit (Illumina, Inc., San Diego, CA, USA) following the manufacturer's instructions. Libraries were subjected to paired-end sequencing of 45-bp reads on the NextSeq500 System (Illumina, Inc.) using NextSeq500 High Output v2 Kit (Illumina). Briefly, the reads were aligned to the University of California, Santa Cruz, reference human genome 19 (hg19) using Spliced Transcripts Alignment to a Reference (STAR) software v2.3.1 (DNASTAR, Inc. Madison, WI, USA). Differentially expressed genes were detected using DESeq v.1.24.0 (Bioconductor open-development software project).

Statistical analysis. For continuous variables, the data are expressed as the mean \pm standard deviation. Cell viability and differences between treatment groups and in vitro assay data were analyzed using MS Excel. A $p$-value of less than 0.05 was considered statistically significant. All statistical analyses were performed using JMP software (SAS Institute, Cary, NC, USA). 

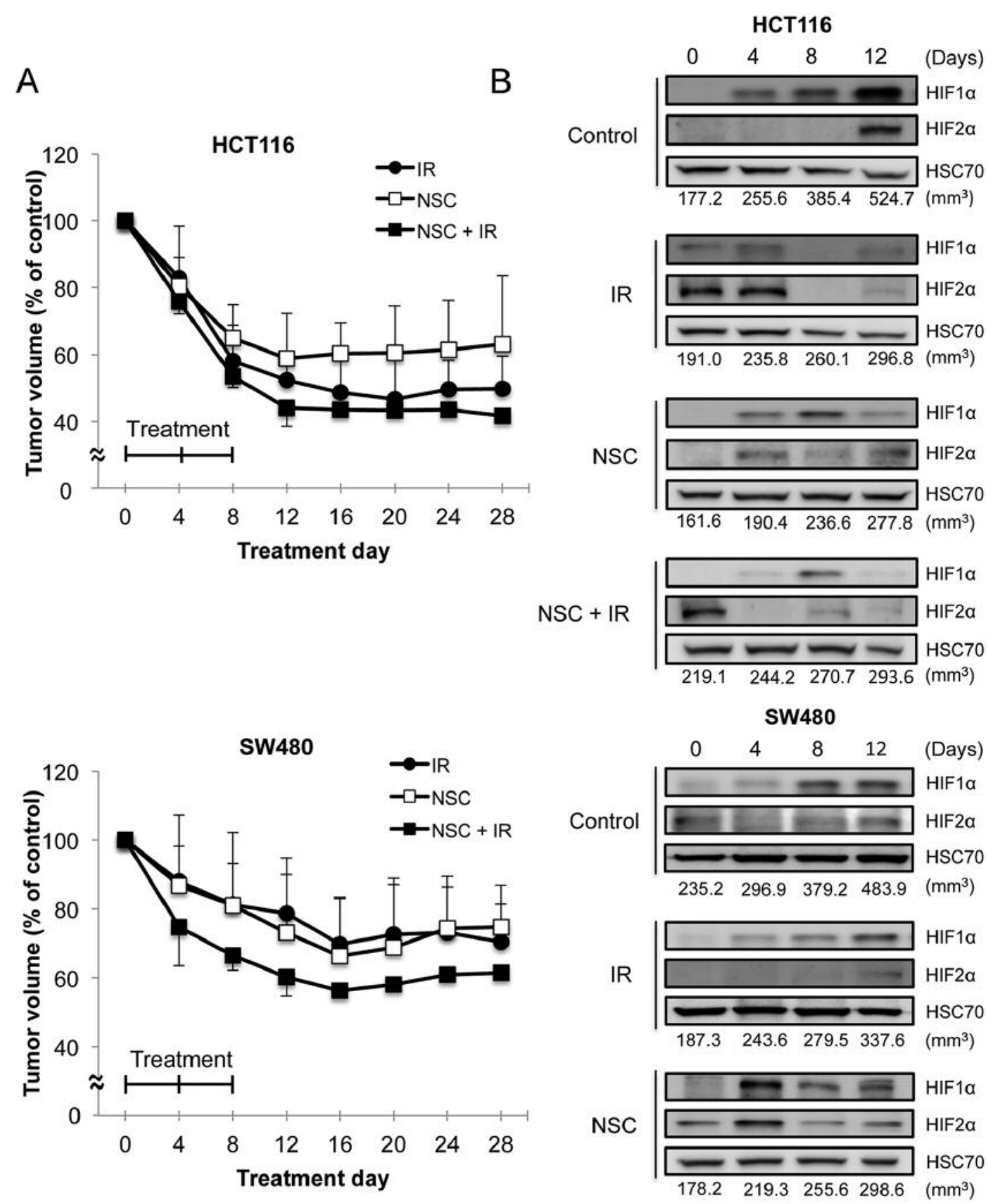

$N S C+I R$

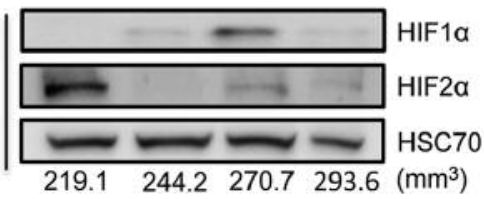

SW480

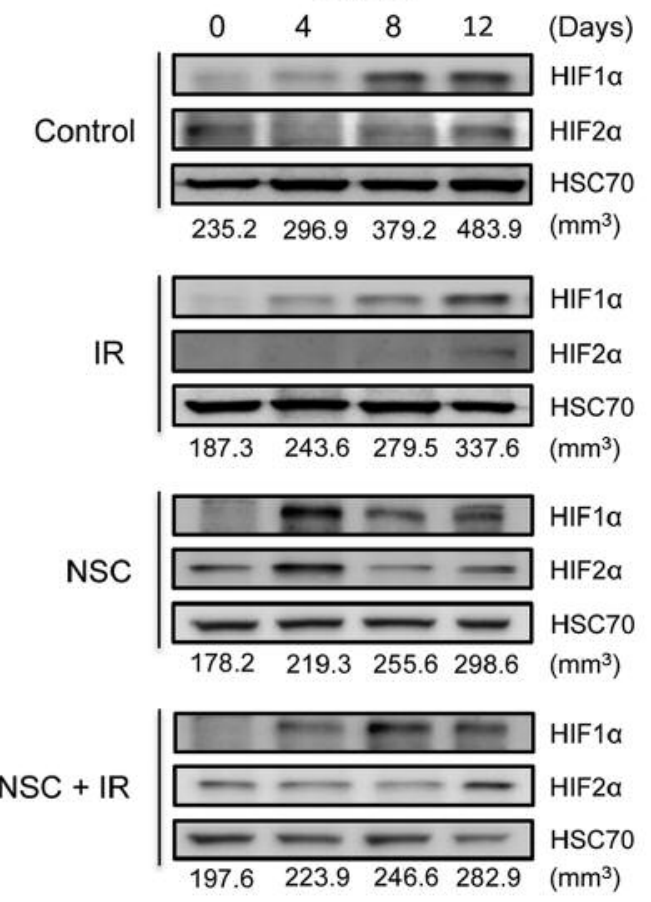

Figure 4. The combination effect of NSC697923 with radiation induced tumor-growth inhibition in mouse xenograft models. A: Tumor volume in mouse xenograft models of SW480 and HCT116 cells treated with radiation (IR) with/without NSC697923 (NSC). The combination was effective against tumor xenografts of both HCT116 and SW480, especially against radiation-resistant SW480 xenografts. Tumor volume was normalized to that of non-treated controls. Radiation was performed on day 0 and intra-peritoneal injection of NSC697923 on 0, 4 and 8. B: Time course of hypoxia-inducible factor 1 alpha subunit (HIFl $\alpha$ ) and $-2 \alpha$ expression and volume of the tumor xenografts. Western blotting was used to evaluate HIF $1 \alpha$ and $-2 \alpha$ expression. HIF $1 \alpha$ and $-2 \alpha$ suppression with the combination of NSC697923 and radiation were not prominent even at day 12 . The expression of these proteins was normalized to the level of heat-shock cognate protein 70 (HSC70). 

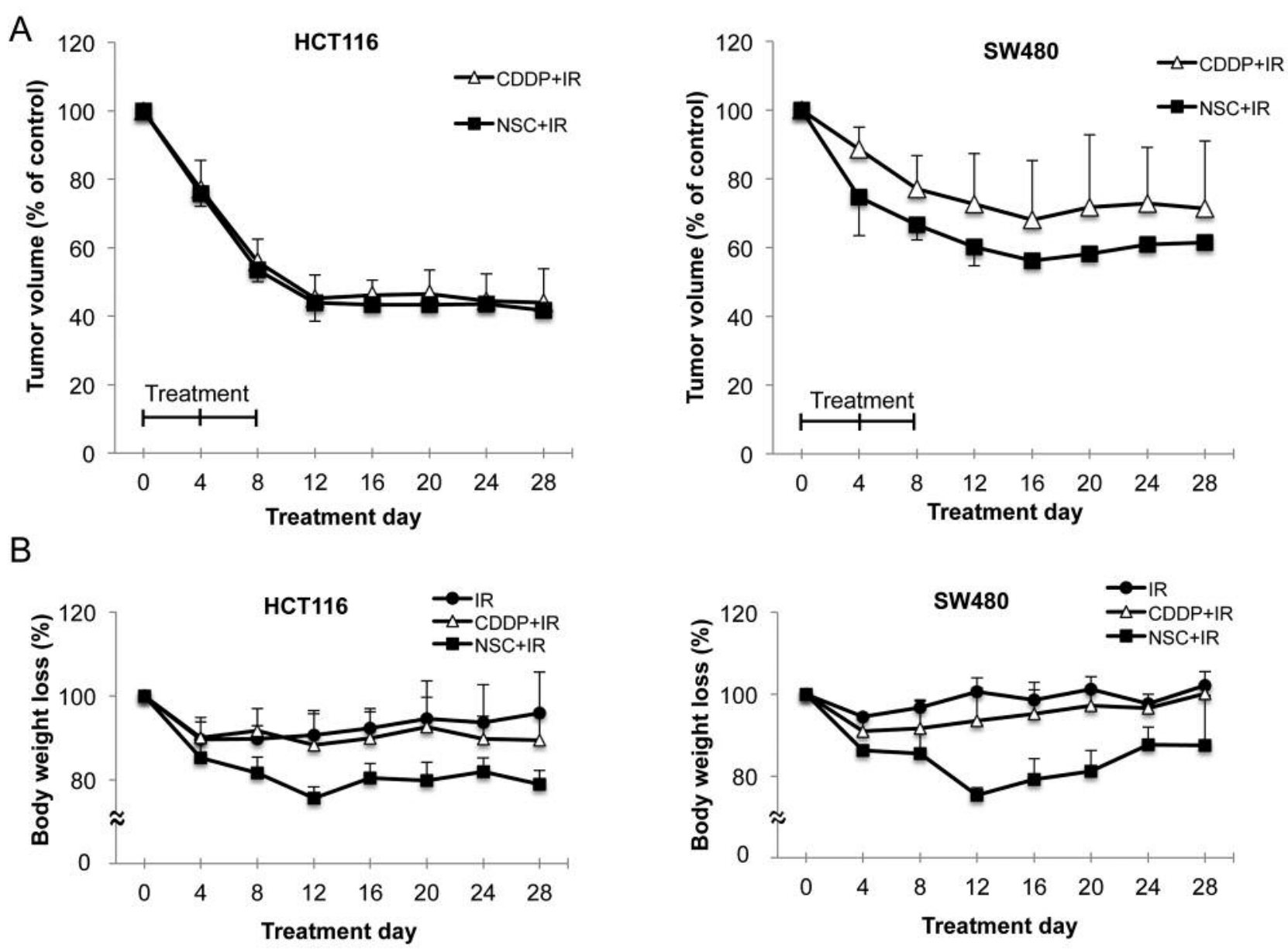

Figure 5. NSC697923 overcomes radiation resistance in SW480 cells more than radiation-modulator cisplatin does. A: Tumor volume in mouse xenograft models of SW480 and HCT116 cells treated with radiation (IR) with cisplatin (CDDP) or NSC697923 (NSC). Tumor volume was normalized to non-treated controls. B: Percentage of body weight loss in xenografted mice treated with IR alone, and IR with CDDP or NSC697923. Body weight was normalized to that of the non-treated control.

\section{Results}

In vitro radiation sensitivity of $C R C$ cell lines in a normoxic environment. We treated several CRC cells with radiation in doses of $0,2,6$, and 10 Gy to examine their sensitivity to radiation (Figure 1A). Among a total of seven cell lines investigated, we selected HCT116 and SW480 cells as the most radiation-sensitive and -resistant lines, respectively, to use in the subsequent experiments. Cell viability in radiationsensitive HCT116 cells was significantly suppressed compared to radiation-resistant SW480 cells at all treatment doses $(p<0.0001)$ (Figure 1A). We then checked the expression of HIF $1 \alpha$ and $-2 \alpha$ in the 2 cell lines. Western-blot analysis showed that baseline-expression levels of both HIF1 $\alpha$ and $-2 \alpha$ were higher in SW480 than those in HCT116 cells, which was likely related to cellular level of resistance to radiation (Figure 1B).
Accumulation of HIFs under hypoxia and radiation resistance. To clarify whether hypoxia causes an increase in cell resistance to radiation as a result of induction of HIF1 $\alpha$ or HIF-2 $\alpha$, HCT116 and SW480 cells were exposed to hypoxia $\left(1 \% \mathrm{O}_{2}\right)$ for $24 \mathrm{~h}$, and then treated with radiation $(6$ Gy). Cellular sensitivity to radiation was evaluated by CCK8 assay after $72 \mathrm{~h}$ incubation under normoxia. Hypoxia caused a statistically significant increase of cellular resistance to radiation in both cell lines as compared with normoxia (Figure 2A). Cell viability increased from $37.2 \%$ to $52.7 \%$ in HCT116 cells $(p<0.001)$ and from $77.3 \%$ to $88.5 \%$ in SW480 cells $(p<0.05)$ under hypoxia (Figure $2 \mathrm{~A})$. We also performed time-course analysis of HIF1 $\alpha$ and $-2 \alpha$ expression under hypoxia. It demonstrated that expression of both proteins was significantly induced and reached a peak $6 \mathrm{~h}$ after the initial exposure to hypoxia in both cell lines. However, expression subsequently declined distinctly rapidly 


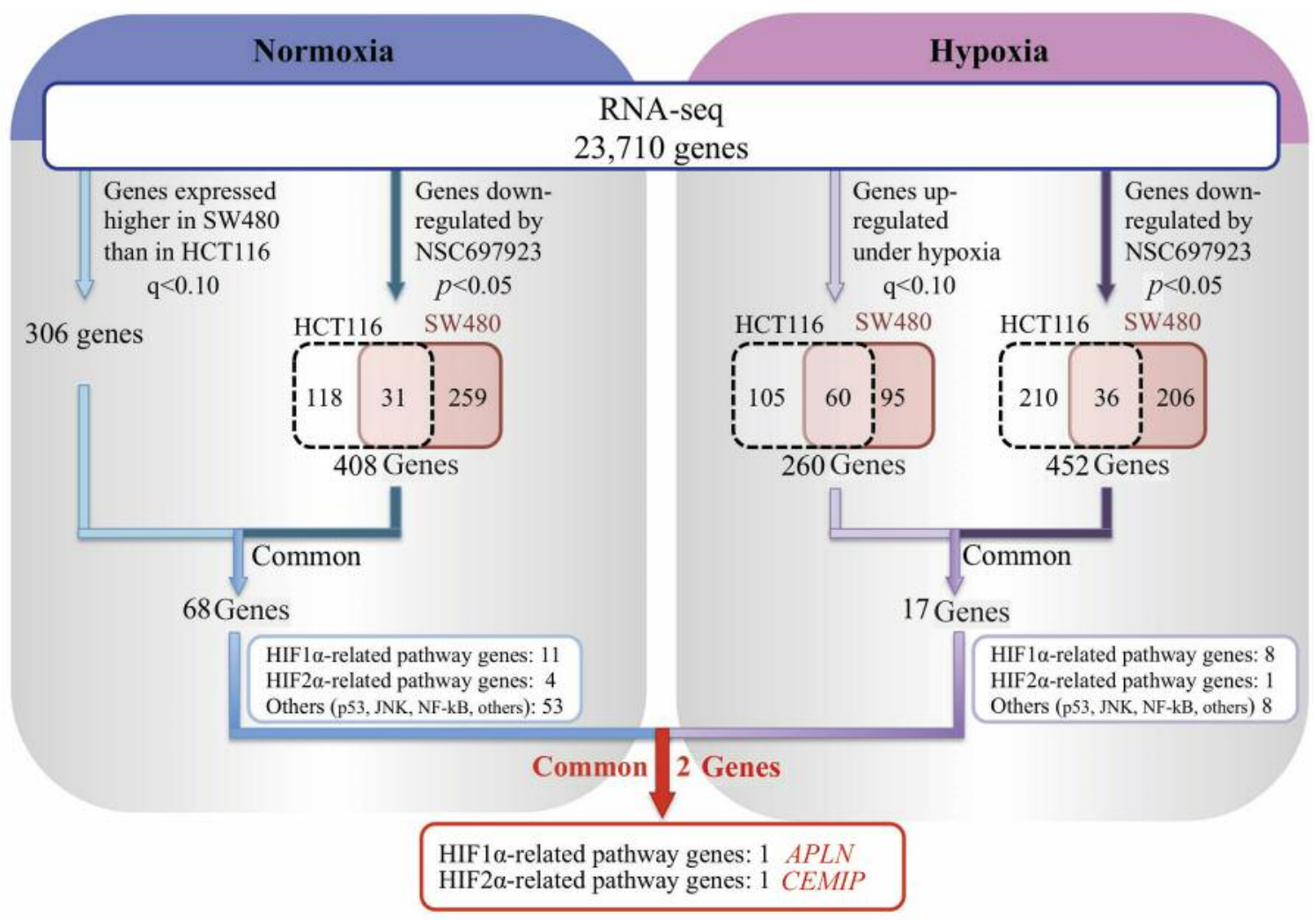

Figure 6. Analytical method of RNA sequencing to identify promising targets of NSC697923 under normoxic and hypoxic conditions. We chose 68 (Table I) and 17 (Table II) genes as targets down-regulated by NSC697923 under normoxic and hypoxic conditions, respectively. From these targets, we found two genes, apelin (APLN) and hyaluronan binding (CEMIP), that were classified as downstream pathway genes of HIF1 $\alpha$ and $-2 \alpha$, respectively, under both normoxic and hypoxic conditions.

in radiation-sensitive HCT116 cells and gradually in radiation-resistant SW480 cells (Figure 2B).

UBE2 inhibitor can repress $H I F 1 \alpha$ and $-2 \alpha$ expression in radiation-resistant $S W 480$ cells even under hypoxia. Increased expression of HIF $1 \alpha$ or $-2 \alpha$ was probably a critical cause of the cellular resistance to radiation. Hence we examined NSC697923 as a possible modulator to overcome radiation resistance in CRC cells. HCT116 and SW480 cells were pre-incubated for $24 \mathrm{~h}$ in 96 -well plates, exposed to NSC697923, and then treated with 6 Gy radiation after $24 \mathrm{~h}$ of drug treatment. We found that NSC697923 significantly repressed expression of both HIF $1 \alpha$ and $-2 \alpha$ induced by hypoxia in SW480 cells, although such remarkable suppression was not observed in HCT116 cells (Figure 3A). Associated with the repressive effect on HIF1 $\alpha$ and $-2 \alpha$, NSC697923 induced significant cytotoxicity, especially against SW480 cells, even when used by itself, and its combination with radiation yielded the most remarkable cellgrowth inhibition of both HCT116 and SW480 cells even under hypoxic conditions (Figure 3B).
Effect of NSC697923 combination with radiation in a mouse xenograft model. Nude mouse experiments were performed to determine the activity of NSC697923 in vivo. Similar to the in vitro analyses, we confirmed that the combination of NSC697923 with radiation was the most active treatment against both tumor xenograft types, HCT116 and SW480, among all treatments investigated (Figure 4A). The combination inhibited tumor growth more than single treatment with IR or NSC697923 alone, although the therapeutic advantage was limited against HCT116 tumors.

Expression of HIF $1 \alpha$ and $-2 \alpha$ in tumors increased with increasing tumor growth in the control groups (Figure 4B). In the HCT116 xenograft system, HIF expression was repressed by all treatments investigated, likely due to tumor growth inhibition (Figure 4B). Nevertheless, these correlations were not clearly observed in the SW480 xenograft system. A decrease of HIF $1 \alpha$ and $-2 \alpha$ expression in the combination group of NSC697923 and radiation was not so prominent and expression was similar to those in the other treatment groups.

Nevertheless, radiation combined with NSC697923 was most active against both radiation-sensitive and -resistant 
Table I. Genes significantly suppressed after NSC697923 treatment under normoxia. We chose 68 genes altered under normoxic conditions as possible targets of NSC697923 from the results of the next-generation RNA sequencing.

\begin{tabular}{|c|c|c|c|c|c|c|}
\hline \multirow{2}{*}{$\begin{array}{l}\text { Related } \\
\text { pathway }\end{array}$} & \multirow[t]{2}{*}{ Symbol } & \multirow[t]{2}{*}{ Gene name } & \multicolumn{2}{|c|}{ HCT116 } & \multicolumn{2}{|c|}{ SW480 } \\
\hline & & & $\begin{array}{l}\text { Log2 fold } \\
\text { change }\end{array}$ & $p$-Value & $\begin{array}{l}\text { Log2 fold } \\
\text { change }\end{array}$ & $p$-Value \\
\hline \multirow[t]{11}{*}{ HIF- $1 \alpha$} & $I G F B P 7$ & Insulin-like growth factor binding protein 7 & 0.23 & $1.00 \mathrm{E}+00$ & -0.77 & 8.64E-05 \\
\hline & CHI3L1 & Chitinase 3-like 1 (cartilage glycoprotein-39) & 1.23 & $8.11 \mathrm{E}-01$ & -0.76 & 3.03E-06 \\
\hline & $C E B P D$ & CCAAT/enhancer binding protein $(\mathrm{C} / \mathrm{EBP})$, delta & 0.33 & $4.23 \mathrm{E}-01$ & -0.48 & 2.16E-03 \\
\hline & $F A B P 3$ & Fatty acid binding protein 3 , muscle and heart & 1.23 & $8.11 \mathrm{E}-01$ & -0.46 & 5.97E-03 \\
\hline & $A P L N$ & Apelin* & 0.13 & $9.40 \mathrm{E}-01$ & -0.42 & 2.01E-02 \\
\hline & $V L D L R$ & Very low density lipoprotein receptor & 1.23 & $8.11 \mathrm{E}-01$ & -0.40 & 1.04E-02 \\
\hline & $S L C 2 A 3$ & Solute carrier family 2 (facilitated glucose transporter), member 3 & 1.49 & 2.02E-05 & -0.34 & 1.54E-02 \\
\hline & ASCL2 & Achaete-scute family bHLH transcription factor 2 & 1.23 & 8.11E-01 & -0.33 & 3.77E-02 \\
\hline & NEDD9 & Neural precursor cell expressed, developmentally down-regulated 9 & 1.97 & $4.22 \mathrm{E}-01$ & -0.33 & 3.13E-02 \\
\hline & OXR1 & Oxidation resistance 1 & -0.23 & $4.31 \mathrm{E}-01$ & -0.33 & 2.00E-02 \\
\hline & $B A C E 2$ & Beta-site APP-cleaving enzyme 2 & 0.10 & 7.57E-01 & -0.33 & 2.48E-02 \\
\hline HIF- $1 \alpha /-2 \alpha$ & CXCR4 & Chemokine (C-X-C motif) receptor 4 & 3.47 & 2.68E-03 & -0.40 & 1.03E-02 \\
\hline \multirow[t]{3}{*}{ HIF- $2 \alpha$} & CEMIP & Cell migration-inducing protein, hyaluronan binding* & -0.42 & $4.06 \mathrm{E}-01$ & -0.72 & 4.41E-06 \\
\hline & ACSS2 & Acyl-CoA synthetase short-chain family member 2 & -0.01 & $9.74 \mathrm{E}-01$ & -0.59 & 5.53E-05 \\
\hline & $C Y B R D 1$ & Cytochrome $\mathrm{b}$ reductase 1 & -0.12 & $6.99 \mathrm{E}-01$ & -0.29 & 4.44E-02 \\
\hline \multirow[t]{7}{*}{ p53 } & IFITM1 & Interferon induced transmembrane protein 1 & -0.18 & $1.00 \mathrm{E}+00$ & -0.90 & 3.83E-06 \\
\hline & $C D K 15$ & Cyclin-dependent kinase 15 & 0.23 & $1.00 \mathrm{E}+00$ & -0.66 & $4.85 \mathrm{E}-04$ \\
\hline & IFI27 & Interferon, alpha-inducible protein 27 & -0.22 & $8.87 \mathrm{E}-01$ & -0.47 & 8.41E-03 \\
\hline & $A B C B 4$ & ATP-binding cassette, sub-family B (MDR/TAP), member 4 & 2.56 & $5.87 \mathrm{E}-01$ & -0.46 & $3.76 \mathrm{E}-02$ \\
\hline & C2orf54 & Chromosome 2 open reading frame 54 & 1.42 & $2.69 \mathrm{E}-01$ & -0.39 & $1.29 \mathrm{E}-02$ \\
\hline & STRA6 & Stimulated by retinoic acid 6 & 0.82 & $9.49 \mathrm{E}-01$ & -0.34 & 1.92E-02 \\
\hline & KCNJ5 & Potassium channel, inwardly rectifying subfamily $\mathrm{J}$, member 5 & 1.23 & $5.90 \mathrm{E}-01$ & -0.32 & 3.05E-02 \\
\hline \multirow[t]{6}{*}{ NF-kB } & CXCL14 & Chemokine (C-X-C motif) ligand 14 & 0.23 & $9.85 \mathrm{E}-01$ & -1.18 & 6.32E-08 \\
\hline & TNFRSF $11 B$ & Tumor necrosis factor receptor superfamily, member $11 \mathrm{~b}$ & -0.77 & $8.79 \mathrm{E}-01$ & -0.70 & 2.53E-05 \\
\hline & $R G C C$ & Regulator of cell cycle & -0.06 & $9.37 \mathrm{E}-01$ & -0.39 & 1.01E-02 \\
\hline & ZAP70 & Zeta-chain (TCR) associated protein kinase $70 \mathrm{kDa}$ & 2.23 & $4.56 \mathrm{E}-01$ & -0.37 & 2.10E-02 \\
\hline & TNFRSF 19 & Tumor necrosis factor receptor superfamily, member 19 & -0.91 & 4.44E-01 & -0.31 & 4.43E-02 \\
\hline & $M P Z L 2$ & Myelin protein zero-like 2 & 0.14 & $6.87 \mathrm{E}-01$ & -0.29 & 4.40E-02 \\
\hline \multirow[t]{6}{*}{ JNK } & CST1 & Cystatin SN & 0.23 & $9.85 \mathrm{E}-01$ & -0.97 & 1.68E-06 \\
\hline & $D K K 3$ & Dickkopf WNT signaling pathway inhibitor 3 & 1.23 & $3.63 \mathrm{E}-01$ & -0.58 & 7.87E-04 \\
\hline & $S A A 1$ & Serum amyloid A1 & 0.23 & $1.00 \mathrm{E}+00$ & -0.47 & 1.37E-03 \\
\hline & KRT5 & Keratin 5, type II & 2.18 & $1.04 \mathrm{E}-01$ & -0.33 & $1.85 \mathrm{E}-02$ \\
\hline & $T G M 2$ & Transglutaminase 2 & 0.76 & 9.99E-03 & -0.32 & 2.29E-02 \\
\hline & WNT6 & Wingless-type MMTV integration site family, member 6 & -0.13 & $9.27 \mathrm{E}-01$ & -0.33 & 2.97E-02 \\
\hline Cholesterol & $A P O E$ & Apolipoprotein E & 1.59 & $9.25 \mathrm{E}-02$ & -0.53 & 7.96E-04 \\
\hline \multirow[t]{17}{*}{ biosynthesis } & $C C D C 3$ & Coiled-coil domain containing 3 & -0.31 & $3.14 \mathrm{E}-01$ & -0.35 & 1.62E-02 \\
\hline & KANK4 & KN motif and ankyrin repeat domains 4 & 0.23 & $1.00 \mathrm{E}+00$ & -1.11 & $1.98 \mathrm{E}-07$ \\
\hline & MYH7B & Myosin, heavy chain 7B, cardiac muscle, beta & 0.13 & $9.79 \mathrm{E}-01$ & -0.93 & 1.13E-10 \\
\hline & UROC1 & Urocanate hydratase 1 & 1.23 & $8.26 \mathrm{E}-01$ & -0.84 & 8.27E-07 \\
\hline & RASL11B & RAS-like, family 11 , member B & 0.89 & $6.74 \mathrm{E}-01$ & -0.83 & 7.84E-06 \\
\hline & $R L B P 1$ & Retinaldehyde binding protein 1 & 0.23 & $1.00 \mathrm{E}+00$ & -0.79 & 1.59E-04 \\
\hline & VIL1 & Cillin 1 & 0.82 & $9.49 \mathrm{E}-01$ & -0.64 & 2.46E-03 \\
\hline & $C D 8 B$ & CD8b molecule & 0.23 & $1.00 \mathrm{E}+00$ & -0.58 & 1.55E-02 \\
\hline & $C B S$ & Cystathionine-beta-synthase & -0.35 & $1.00 \mathrm{E}+00$ & -0.57 & 7.81E-04 \\
\hline & KCNA6 & Potassium channel, voltage gated shaker related subfamily A, member 6 & 0.23 & $1.00 \mathrm{E}+00$ & -0.57 & $5.29 \mathrm{E}-03$ \\
\hline & $G Y G 2$ & Glycogenin 2 & 0.23 & $1.00 \mathrm{E}+00$ & -0.54 & 3.75E-03 \\
\hline & $Q P R T$ & Quinolinate phosphoribosyltransferase & -0.18 & $1.00 \mathrm{E}+00$ & -0.51 & 2.11E-03 \\
\hline & $\mathrm{CDH} 13$ & Cadherin 13 & 0.23 & $1.00 \mathrm{E}+00$ & -0.48 & 9.33E-03 \\
\hline & SDK1 & Sidekick cell adhesion molecule 1 & 2.23 & $5.21 \mathrm{E}-01$ & -0.48 & $1.92 \mathrm{E}-03$ \\
\hline & MYO1D & Myosin ID & -0.24 & $4.00 \mathrm{E}-01$ & -0.47 & 7.03E-04 \\
\hline & PSG1 & Pregnancy specific beta-1-glycoprotein 1 & 0.23 & $9.85 \mathrm{E}-01$ & -0.44 & 4.14E-03 \\
\hline & ACSS1 & Acyl-CoA synthetase short-chain family member 1 & 0.23 & $9.85 \mathrm{E}-01$ & -0.43 & 5.71E-03 \\
\hline Other & SLC7A7 & $\begin{array}{l}\text { Solute carrier family } 7 \text { (amino acid transporter } \\
\text { light chain, } y+L \text { system), member } 7\end{array}$ & 1.82 & $6.19 \mathrm{E}-01$ & -0.40 & $1.47 \mathrm{E}-02$ \\
\hline
\end{tabular}


Table I. Continued

\begin{tabular}{|c|c|c|c|c|c|c|}
\hline \multirow{2}{*}{$\begin{array}{l}\text { Related } \\
\text { pathway }\end{array}$} & \multirow[t]{2}{*}{ Symbol } & \multirow[t]{2}{*}{ Gene name } & \multicolumn{2}{|c|}{ HCT116 } & \multicolumn{2}{|c|}{ SW480 } \\
\hline & & & $\begin{array}{l}\text { Log2 fold } \\
\text { change }\end{array}$ & $p$-Value & $\begin{array}{l}\log 2 \text { fold } \\
\text { change }\end{array}$ & $p$-Value \\
\hline & $A P C D D 1$ & Adenomatosis polyposis coli down-regulated 1 & 2.82 & $3.27 \mathrm{E}-01$ & -0.39 & 5.14E-03 \\
\hline & TMEM163 & Transmembrane protein 163 & 1.23 & $9.65 \mathrm{E}-01$ & -0.39 & $3.46 E-02$ \\
\hline & SERPINA1 & $\begin{array}{l}\text { Serpin peptidase inhibitor, clade A (alpha- } 1 \\
\text { antiproteinase, antitrypsin), member } 1\end{array}$ & -0.03 & $9.92 \mathrm{E}-01$ & -0.39 & 1.41E-02 \\
\hline & ISMI & Isthmin 1 , angiogenesis inhibitor & 0.12 & $9.29 \mathrm{E}-01$ & -0.38 & 1.90E-02 \\
\hline & $H U N K$ & Hormonally up-regulated Neu-associated kinase & 0.23 & $1.00 \mathrm{E}+00$ & -0.37 & 1.11E-02 \\
\hline & ADAMTS15 & ADAM metallopeptidase with thrombospondin type 1 motif, 15 & -1.27 & $1.30 \mathrm{E}-01$ & -0.35 & 4.47E-02 \\
\hline & $K I F 26 B$ & Kinesin family member $26 \mathrm{~B}$ & 0.30 & $7.25 \mathrm{E}-01$ & -0.35 & 4.46E-02 \\
\hline & KRT13 & Keratin 13 , type I & 0.06 & $1.00 \mathrm{E}+00$ & -0.33 & 3.58E-02 \\
\hline & TMEM139 & Transmembrane protein 139 & 0.74 & $3.51 \mathrm{E}-01$ & -0.32 & 3.53E-02 \\
\hline & CLSTN2 & Calsyntenin 2 & 0.23 & $9.85 \mathrm{E}-01$ & -0.31 & 4.72E-02 \\
\hline & HEG1 & Heart development protein with EGF-like domains 1 & 0.31 & $3.43 \mathrm{E}-01$ & -0.29 & 4.65E-02 \\
\hline & TMEM45B & Transmembrane protein $45 \mathrm{~B}$ & 0.23 & $9.85 \mathrm{E}-01$ & -0.29 & 4.72E-02 \\
\hline & $S P T B$ & Spectrin, beta, erythrocytic & -0.87 & 3.06E-02 & -0.45 & 3.11E-03 \\
\hline & $A R L 4 C$ & ADP-ribosylation factor-like $4 \mathrm{C}$ & -0.72 & 4.35E-02 & -0.20 & $1.78 \mathrm{E}-01$ \\
\hline & KRT23 & Keratin 23 , type I & -0.88 & 2.94E-02 & -0.11 & 4.35E-01 \\
\hline
\end{tabular}

Significant $p$-values $(<0.05)$ are shown in bold and reflect genes significantly up-/down-regulated. *Genes down-regulated under both normoxia and hypoxia.

tumor xenografts, and had a therapeutic advantage in combination to radiation even compared with a well-known radiation-modulator, cisplatin (Figure 5A). For SW480 tumors, the combination treatment of radiation with NSC697923 inhibited tumor growth more than the combination of radiation and cisplatin, with tolerable toxicity (Figure 5B).

These results led us to hypothesize that the repression of HIF $1 \alpha$ and $-2 \alpha$ would not be always the main action mechanism of NSC697923, and that the nude mouse xenograft system would not always be able to correctly evaluate the activity of drugs targeting HIFs. NSC697923 might repress HIF $1 \alpha$ and $-2 \alpha$ and shrink lesions with high expression of these proteins. This might explain why the expression of HIF $1 \alpha$ and $-2 \alpha$ in residual tumors was apparently not related to the antitumor activity of NSC697923.

NSC697923 modulates several radiation-resistant pathways including, HIF $1 \alpha$ and $-2 \alpha$, in SW480 cells. NSC697923 may have more pertinent molecular targets than HIF1 $\alpha$ and $-2 \alpha$. We attempted to search for other probable action determinants of NSC697923 using NGS. RNA sequencing of radiation-sensitive HCT116 and radiation-resistant SW480 cells was performed after incubation under normoxia or hypoxia, with and without NSC697923 treatment. We then chose genes expressed at higher levels in radiation-resistant SW480 than in radiation-sensitive HCT116 cells under normoxic conditions. We also chose genes that were more up-regulated under hypoxic conditions, and further downregulated after NSC697923 treatment under both normoxic and hypoxic conditions in both cell lines, matched for any anticancer activity induced by the drug (Figure 6). We chose 68 genes (Table I) in normoxic, and 17 genes (Table II) in hypoxic conditions as possible targets of NSC697923. Among these genes, we noted apelin $(A P L N)$ and cell migration-inducing protein, hyaluronan binding protein $(C E M I P)$, which have recently attracted attention as factors in HIF1 and -2 pathways.

\section{Discussion}

In this study, we found that NSC697923 can overcome radiation resistance via suppression of HIF1 $\alpha$ and $-2 \alpha$ expression in in vitro and in vivo analysis. For in vivo analysis, the combination of NSC697923 with radiation was more effective than that with an established radiation modulator, cisplatin. Next-generation RNA sequencing showed that NSC697923 treatment can suppress HIF family pathway genes, including $A P L N$ and CEMIP, under both normoxic and hypoxic conditions.

Radiation resistance is a serious problem for patients with CRC. Resistance is induced by various pathways, including hypoxia, receptor tyrosine kinase/protein kinase B (RTK/AKT), DNA damage repair, adhesion pathway, inflammation and developmental pathway $(26,27)$. In this study, we focused on the HIF pathway to overcome radiation 
Table II. Genes significantly suppressed after NSC697923 treatment under hypoxia. We chose 17 genes altered under hypoxic conditions as possible targets of NSC697923 from the results of the next-generation RNA sequencing.

\begin{tabular}{|c|c|c|c|c|c|c|}
\hline \multirow{2}{*}{$\begin{array}{l}\text { Related } \\
\text { pathway }\end{array}$} & \multirow[t]{2}{*}{ Symbol } & \multirow[t]{2}{*}{ Gene name } & \multicolumn{2}{|c|}{ HCT116 } & \multicolumn{2}{|c|}{ SW480 } \\
\hline & & & $\begin{array}{l}\log 2 \text { fold } \\
\text { change }\end{array}$ & $p$-Value & $\begin{array}{c}\log 2 \text { fold } \\
\text { change }\end{array}$ & $p$-Value \\
\hline \multirow[t]{8}{*}{ HIF- $1 \alpha$} & FGF11 & Fibroblast growth factor 11 & -0.22 & $6.54 \mathrm{E}-01$ & -0.51 & $1.20 \mathrm{E}-02$ \\
\hline & $A P L N$ & Apelin* & -0.24 & 8.33E-01 & -0.48 & 1.90E-03 \\
\hline & ETS2 & V-ets avian erythroblastosis virus E26 oncogene homolog 2 & 0.05 & 8.67E-01 & -0.38 & 1.00E-02 \\
\hline & ASNS & Asparagine synthetase (glutamine-hydrolyzing) & -0.23 & $4.00 \mathrm{E}-01$ & -0.31 & 3.68E-02 \\
\hline & MIR210HG & MIR210 host gene & -0.77 & $1.36 \mathrm{E}-02$ & -0.42 & 3.04E-02 \\
\hline & ZNF395 & Zinc finger protein 395 & -0.62 & 2.31E-02 & -0.36 & $1.58 \mathrm{E}-02$ \\
\hline & WDR54 & WD repeat domain 54 & -0.85 & 4.70E-03 & -0.22 & $2.18 \mathrm{E}-01$ \\
\hline & $B N I P 3$ & BCL2/adenovirus E1B 19kDa interacting protein 3 & -0.54 & 4.71E-02 & -0.69 & $9.71 \mathrm{E}-01$ \\
\hline HIF- $2 \alpha$ & CEMIP & Cell migration-inducing protein, hyaluronan binding* & -0.90 & $5.98 \mathrm{E}-02$ & -0.65 & 1.22E-05 \\
\hline p53 & FGD5 & FYVE, RhoGEF and PH domain containing 5 & -1.42 & 7.47E-01 & -0.36 & 1.82E-02 \\
\hline JNK & TRPV4 & Transient receptor potential cation channel, subfamily V, member 4 & -0.87 & 4.87E-01 & -0.47 & 1.77E-02 \\
\hline \multirow[t]{6}{*}{ Others } & KCNJ10 & Potassium channel, inwardly rectifying subfamily $\mathrm{J}$, member 10 & -0.92 & $5.70 \mathrm{E}-01$ & -0.49 & $9.52 E-03$ \\
\hline & CHST15 & Carbohydrate (N-acetylgalactosamine 4-sulfate 6-O) sulfotransferase 15 & 0.20 & 4.67E-01 & -0.40 & 6.59E-03 \\
\hline & GPR146 & G protein-coupled receptor 146 & -1.29 & 1.33E-02 & -0.25 & $6.27 \mathrm{E}-01$ \\
\hline & KIAA0895L & KIAA0895-like & -0.72 & 1.91E-02 & -0.08 & 7.69E-01 \\
\hline & BCKDHA & Branched chain keto acid dehydrogenase E1, alpha polypeptide & -0.67 & 2.98E-02 & -0.18 & $2.77 \mathrm{E}-01$ \\
\hline & HIFO & $\mathrm{H} 1$ histone family, member 0 & -0.55 & 3.89E-02 & -0.13 & 3.65E-01 \\
\hline
\end{tabular}

Significant $p$-values $(<0.05)$ are shown in bold and reflect genes significantly up-/down-regulated. *Genes down-regulated under both normoxia and hypoxia.

resistance because HIF1 $\alpha$ activity is well known to be associated with radiation resistance, angiogenesis, cell survival, and proliferation in cancer cells (28-30). Some representative HIF downstream genes have already been reported as angiogenesis mediators, including nitric oxide synthase $(N O S)$, and vascular endothelial growth factor $(V E G F)$; cell-survival regulators include insulin-like growth factor (IGF)-related factors and cell-proliferation regulators include $c-M Y C, N O S$, and $I G F 2$. Such genes are induced and associated with radiation resistance under hypoxic conditions. Numerous studies have analyzed putative HIF1 $\alpha$ and $-2 \alpha$ suppression mechanisms focusing on transcriptional level, translation, stabilization, dimerization, DNA binding, and transcriptional activity of down-stream genes $(31,32)$.

We also focused on the UBE2 family, which was already reported to suppress the Von Hippel-Lindau tumor suppressor, E3 ubiquitin protein (VHL) (28). VHL degrades HIF1 $\alpha$ and $2 \alpha$ via proteasome systems, hence UBE2 family inhibitors can induce HIF suppression via VHL accumulation. Our data showed in both in vitro and in vivo analyses that the UBE2 inhibitor NSC697923 can suppress HIF1 $\alpha$ and $-2 \alpha$ expression and overcome radiation resistance. Interestingly, it was already reported that NSC697923 can induce anticancer effects by targeting some cancer-related genes, including nuclear factor of kappa light polypeptide gene enhancer in B-cells (NF-kB) $(24,25)$, c-Jun $N$-terminal kinase (JNK) and p53 (23), which are linked to radiation resistance in various types of cancer
$(33,34)$. Based on our results, we believe that the combination therapy of NSC697923 and radiation might be a promising strategy to overcome radiation resistance by suppressing the HIF $1 \alpha$ and $-2 \alpha$ family pathways.

We focused on NSC697923 as a radiation modulator under hypoxic conditions, but single-drug treatment can induce antitumor effects in both normoxia and hypoxia. Another possible pathway might be related to the action of NSC697923. Several recent studies have shown that NSC697923 induced cancer cell death by targeting the JNK pathway, DNA damage signaling, NF-kB signaling, the mitogen-activated protein kinase (MAPK) pathway and p53mediated apoptosis (23-25): p53 is an important tumor suppressor, regulating cellular apoptosis, survival and HIF stabilization $(35,36)$. In our study, baseline expression of HIFs in SW480 cells was higher than that of HCT116 cells under normoxic conditions. It is possible that survival of SW480 cells, which harbor p53 mutation, depends on the inactivation of p53 and HIFs, compared with p53 wild-type HCT116 cells. From these previous reports, it has been suggested that NSC697923 monotherapy might have antitumor effects via induction of p53-induced apoptosis.

From our in vivo results, it is possible that NSC697923 might have molecular targets other than HIF1 $\alpha$ and $-2 \alpha$ : Our RNA sequencing data showed that HIF1 $\alpha$-related $A P L N$ and HIF-2 $\alpha$-related CEMIP genes were down-regulated after NSC697923 treatment under both normoxic and hypoxic 
conditions. Previous findings showed that CEMIP is a downstream effector of HIF2 $\alpha$-mediated CRC aggressiveness, and directly facilitated colon tumor growth; high expression correlated with poor outcome in advanced stages of CRC (37, $38)$. In addition, $A P L N$ protected cells from apoptosis and was a potent activator of tumor angiogenesis $(39,40)$. Therefore, tumor-suppressive mechanisms of NSC697923 treatment under normoxic and hypoxic conditions might depend on $A P L N$ and CEMIP, making them promising downstream targets for HIF family in CRC.

Neo-adjuvant radiation and chemoradiotherapy (CRT) are very important therapeutic tools in preventing local recurrence and permanent colostomy after abdominal peritoneal resection (41-43). In the case of radiation-sensitive CRC cells, a pathological complete response is estimated as being achieved in $15-27 \%$ of patients treated with CRT (44), patients with CRC refractory to these therapies often have poor outcomes (45). CRT causes side-effects including pain, urological problems, gastrointestinal bleeding, proctitis and ileus $(46,47)$. From our in vivo data, the toxicity of the combination of NSC697923 and radiation was tolerable, therefore NSC697923 might be useful in patients with colorectal cancer because its combination with radiation can significantly induce cell death even in radiationresistant CRC cells. During treatment, modern radiation technologies, including tomotherapy, intensity-modulated radiotherapy, volumetric intensity-modulated arc therapy and image-guided radiotherapy can protect surrounding normal tissues, and precisely focus on the target radiation field (48-50). These advantages might enable use of this combination therapy with less toxicity for patients with CRC.

In conclusion, this study showed that the UBE2 inhibitor NSC697923 mitigates radiation resistance through suppression of HIF1 $\alpha$ and $-2 \alpha$. NSC697923 might be particularly effective against hypoxia-induced radiation resistance by targeting HIF downstream pathway genes, including $A P L N$ and CEMIP. In considering new molecular cancer therapies, NSC697923 may be a promising radiation modulator against refractory $\mathrm{CRC}$.

\section{Ethics Approval and Consent to Participate}

Mouse experiments were performed in compliance with the guidelines of the Institute for Laboratory Animal Research at Gunma University, Maebashi, Japan.

\section{Competing Interests}

The Authors declare that they have no competing interests in regard to this study.

\section{References}

1 Brenner H, Kloor M and Pox CP: Colorectal cancer. Lancet 383: 1490-1502, 2014.
2 Dienstmann R, Salazar R and Tabernero J: Personalizing colon cancer adjuvant therapy: selecting optimal treatments for individual patients. J Clin Oncol 33: 1787-1796, 2015.

3 Hobday TJ and Erlichman C: Adjuvant therapy of colon cancer: a review. Clin Colorectal Cancer 1: 230-236, 2002.

4 Hellinger MD and Santiago CA: Reoperation for recurrent colorectal cancer. Clin Colon Rectal Surg 19: 228-236, 2006.

5 Park IJ and Yu CS: Current issues in locally advanced colorectal cancer treated by preoperative chemoradiotherapy. World $\mathrm{J}$ Gastroenterol 20: 2023-2029, 2014.

6 Trakarnsanga A, Ithimakin S and Weiser MR: Treatment of locally advanced rectal cancer: controversies and questions. World J Gastroenterol 18: 5521-5532, 2012.

7 Bertout JA, Patel SA and Simon MC: The impact of $\mathrm{O}_{2}$ availability on human cancer. Nat Rev Cancer 8: 967-975, 2008.

8 Ioannou M, Paraskeva E, Baxevanidou K, Simos G, Papamichali R, Papacharalambous C, Samara M and Koukoulis G: HIF1alpha in colorectal carcinoma: review of the literature. J BUON 20: 680-689, 2015

9 Kunz M and Ibrahim SM: Molecular responses to hypoxia in tumor cells. Mol Cancer 2: 23, 2003.

$10 \mathrm{Ke} \mathrm{Q}$ and Costa M: Hypoxia-inducible factor-1 (HIF-1). Mol Pharmacol 70: 1469-1480, 2006.

11 Semenza GL: Hypoxia-inducible factors: mediators of cancer progression and targets for cancer therapy. Trends Pharmacol Sci 33: 207-214, 2012.

12 Keith B, Johnson RS and Simon MC: HIF1alpha and HIF2alpha: sibling rivalry in hypoxic tumour growth and progression. Nat Rev Cancer 12: 9-22, 2012.

13 Wilson WR and Hay MP: Targeting hypoxia in cancer therapy. Nat Rev Cancer 11: 393-410, 2011.

14 Harrison LB, Chadha M, Hill RJ, Hu K and Shasha D: Impact of tumor hypoxia and anemia on radiation therapy outcomes. Oncologist 7: 492-508, 2002.

15 Brown JM and Wilson WR: Exploiting tumour hypoxia in cancer treatment. Nat Rev Cancer 4: 437-447, 2004.

16 Shannon AM, Bouchier-Hayes DJ, Condron CM and Toomey D: Tumour hypoxia, chemotherapeutic resistance and hypoxiarelated therapies. Cancer Treat Rev 29: 297-307, 2003.

17 Yoshimura H, Dhar DK, Kohno H, Kubota H, Fujii T, Ueda S, Kinugasa S, Tachibana $\mathrm{M}$ and Nagasue N: Prognostic impact of hypoxia-inducible factors 1alpha and 2alpha in colorectal cancer patients: correlation with tumor angiogenesis and cyclooxygenase- 2 expression. Clin Cancer Res 10: 8554-8560, 2004.

18 Baba Y, Nosho K, Shima K, Irahara N, Chan AT, Meyerhardt JA, Chung DC, Giovannucci EL, Fuchs CS and Ogino S: HIF1A overexpression is associated with poor prognosis in a cohort of 731 colorectal cancers. Am J Pathol 176: 2292-2301, 2010.

19 Giatromanolaki A, Koukourakis MI, Sivridis E, Turley H, Talks K, Pezzella F, Gatter KC and Harris AL: Relation of hypoxia inducible factor 1 alpha and 2 alpha in operable non-small cell lung cancer to angiogenic/molecular profile of tumours and survival. Br J Cancer 85: 881-890, 2001.

20 Lee K, Kang JE, Park SK, Jin Y, Chung KS, Kim HM, Lee K, Kang MR, Lee MK, Song KB, Yang EG, Lee JJ and Won M: LW6, a novel HIF-1 inhibitor, promotes proteasomal degradation of HIF-1alpha via up-regulation of VHL in a colon cancer cell line. Biochem Pharmacol 80: 982-989, 2010. 
21 Strickson S, Campbell DG, Emmerich CH, Knebel A, Plater L, Ritorto MS, Shpiro N and Cohen P: The anti-inflammatory drug BAY 11-7082 suppresses the MyD88-dependent signalling network by targeting the ubiquitin system. Biochem J 451: 427-437, 2013.

22 Roos FC, Evans AJ, Brenner W, Wondergem B, Klomp J, Heir $\mathrm{P}$, Roche O, Thomas C, Schimmel H, Furge KA, Teh BT, Thuroff JW, Hampel C and Ohh M: Deregulation of E2-EPF ubiquitin carrier protein in papillary renal cell carcinoma. Am J Pathol 178: 853-860, 2011.

23 Cheng J, Fan YH, Xu X, Zhang H, Dou J, Tang Y, Zhong X, Rojas Y, Yu Y, Zhao Y, Vasudevan SA, Zhang H, Nuchtern JG, Kim ES, Chen X, Lu F and Yang J: A small-molecule inhibitor of UBE2N induces neuroblastoma cell death via activation of p53 and JNK pathways. Cell Death Dis 5: e1079, 2014.

24 Pulvino M, Liang Y, Oleksyn D, DeRan M, Van Pelt E, Shapiro J, Sanz I, Chen L and Zhao J: Inhibition of proliferation and survival of diffuse large B-cell lymphoma cells by a smallmolecule inhibitor of the ubiquitin-conjugating enzyme Ubc13Uev1A. Blood 120: 1668-1677, 2012.

25 Hodge CD, Edwards RA, Markin CJ, McDonald D, Pulvino M, Huen MS, Zhao J, Spyracopoulos L, Hendzel MJ and Glover JN: Covalent Inhibition of UBC13 affects ubiquitin signaling and reveals active site elements important for targeting. ACS Chem Biol 10: 1718-1728, 2015.

26 Vaupel P, Thews $\mathrm{O}$ and Hoeckel M: Treatment resistance of solid tumors: role of hypoxia and anemia. Med Oncol 18: 243-259, 2001.

27 Kim BM, Hong Y, Lee S, Liu P, Lim JH, Lee YH, Lee TH, Chang KT and Hong Y: Therapeutic implications for overcoming radiation resistance in cancer therapy. Int J Mol Sci 16: 2688026913, 2015.

28 Semenza GL: Targeting HIF-1 for cancer therapy. Nat Rev Cancer 3: 721-732, 2003.

29 Chan DA, Krieg AJ, Turcotte S and Giaccia AJ: HIF gene expression in cancer therapy. Methods Enzymol 435: 323-345, 2007.

$30 \mathrm{Xia}$ Y, Choi HK and Lee K: Recent advances in hypoxia-inducible factor (HIF)-1 inhibitors. Eur J Med Chem 49: 24-40, 2012.

31 Masoud GN and Li W: HIF-1alpha pathway: role, regulation and intervention for cancer therapy. Acta Pharm Sin B 5: 378-389, 2015.

32 Helbig L, Koi L, Bruchner K, Gurtner K, Hess-Stumpp H, Unterschemmann K, Pruschy M, Baumann M, Yaromina A and Zips D: Hypoxia-inducible factor pathway inhibition resolves tumor hypoxia and improves local tumor control after single-dose irradiation. Int J Radiat Oncol Biol Phys 88: 159-166, 2014.

33 Bai M, Ma X, Li X, Wang X, Mei Q, Li X, Wu Z and Han W: The Accomplices of NF-kappaB Lead to Radioresistance. Curr Protein Pept Sci 16: 279-294, 2015.

34 Aravindan N, Aravindan S, Pandian V, Khan FH, Ramraj SK, Natt $\mathrm{P}$ and Natarajan $\mathrm{M}$ : Acquired tumor cell radiation resistance at the treatment site is mediated through radiation-orchestrated intercellular communication. Int J Radiat Oncol Biol Phys 88 : 677-685, 2014.

$35 \mathrm{Li}$ XL, Zhou J, Chen ZR and Chng WJ: P53 mutations in colorectal cancer - molecular pathogenesis and pharmacological reactivation. World J Gastroenterol 21: 84-93, 2015.

36 Robertson ED, Semenchenko K and Wasylyk B: Crosstalk between Mdm2, p53 and HIF1-alpha: distinct responses to oxygen stress and implications for tumour hypoxia. Subcell Biochem 85: 199-214, 2014.
37 Evensen NA, Li Y, Kuscu C, Liu J, Cathcart J, Banach A, Zhang Q, Li E, Joshi S, Yang J, Denoya PI, Pastorekova S, Zucker S, Shroyer KR and Cao J: Hypoxia promotes colon cancer dissemination through up-regulation of cell migration-inducing protein (CEMIP). Oncotarget 6: 20723-20739, 2015.

38 Fink SP, Myeroff LL, Kariv R, Platzer P, Xin B, Mikkola D, Lawrence E, Morris N, Nosrati A, Willson JK, Willis J, Veigl M, Barnholtz-Sloan JS, Wang Z and Markowitz SD: Induction of KIAA1199/CEMIP is associated with colon cancer phenotype and poor patient survival. Oncotarget 6: 30500-30515, 2015.

39 Picault FX, Chaves-Almagro C, Projetti F, Prats H, Masri B and Audigier Y: Tumour co-expression of apelin and its receptor is the basis of an autocrine loop involved in the growth of colon adenocarcinomas. Eur J Cancer 50: 663-674, 2014.

40 Sorli SC, Le Gonidec S, Knibiehler B and Audigier Y: Apelin is a potent activator of tumour neoangiogenesis. Oncogene 26: 7692-7699, 2007.

41 Petersen SH, Harling H, Kirkeby LT, Wille-Jorgensen P and Mocellin S: Postoperative adjuvant chemotherapy in rectal cancer operated for cure. Cochrane Database Syst Rev: CD004078, 2012.

42 Tamas K, Walenkamp AM, de Vries EG, van Vugt MA, BeetsTan RG, van Etten B, de Groot DJ and Hospers GA: Rectal and colon cancer: Not just a different anatomic site. Cancer Treat Rev 41: 671-679, 2015.

43 Krook JE, Moertel CG, Gunderson LL, Wieand HS, Collins RT, Beart RW, Kubista TP, Poon MA, Meyers WC, Mailliard JA, Twito DI, Morton RF, Veeder MH, Witzig TE, Cha S and Vidyarthi SC: Effective surgical adjuvant therapy for high-risk rectal carcinoma. N Engl J Med 324: 709-715, 1991.

44 Myint AS: Novel radiation techniques for rectal cancer. J Gastrointest Oncol 5: 212-217, 2014.

45 Stintzing S: Management of colorectal cancer. F1000Prime Rep 6: 108, 2014.

46 Akgun Z, Saglam S, Yucel S, Gural Z, Balik E, Cipe G, Yildiz S, Kilickap S, Okyar A and Kaytan-Saglam E: Neoadjuvant chronomodulated capecitabine with radiotherapy in rectal cancer: a phase II brunch regimen study. Cancer Chemother Pharmacol 74: 751-756, 2014.

47 Sahakitrungruang C, Thum-Umnuaysuk S, Patiwongpaisarn A, Atittharnsakul $\mathrm{P}$ and Rojanasakul A: A novel treatment for haemorrhagic radiation proctitis using colonic irrigation and oral antibiotic administration. Colorectal Dis 13: e79-82, 2011.

48 Appelt AL and Sebag-Montefiore D: Technological advances in radiotherapy of rectal cancer: opportunities and challenges. Curr Opin Oncol 28: 353-358, 2016.

49 Weber HE, Droge LH, Hennies S, Herrmann MK, Gaedcke J and Wolff HA: Volumetric intensity-modulated arc therapy vs. 3dimensional conformal radiotherapy for primary chemoradiotherapy of anal carcinoma: Effects on treatment-related side effects and survival. Strahlenther Onkol 191: 827-834, 2015.

50 Sermeus A, Leonard W, Engels B and De Ridder M: Advances in radiotherapy and targeted therapies for rectal cancer. World $\mathrm{J}$ Gastroenterol 20: 1-5, 2014. 